\section{Is the Title Appropriate?}

To the Editor:

I read with interest the excellent article by Jadon, et $a l^{1}$ titled "Serum Soluble Bone Turnover Biomarkers in Psoriatic Arthritis and Psoriatic Spondyloarthropathy" published in the January 2015 issue of The Journal.

Although the title mentions "psoriatic spondyloarthropathy," the authors have not described any study or details pertaining to biomarkers in psoriatic spondyloarthropathy in the entire article. The title is misleading, in my opinion. Thank you.
ABHIJEET DANVE, MD, Research Fellow, Division of Rheumatology, University of Nebraska Medical Center, 11322 Franklin Plaza \#915, Omaha, Nebraska 68154, USA. Address correspondence to Dr. A. Danve, e-mail: drdanve@hotmail.com

\section{REFERENCE}

1. Jadon DR, Nightingale AL, McHugh NJ, Lindsay MA, Korendowych E, Sengupta R. Serum soluble bone turnover biomarkers in psoriatic arthritis and psoriatic spondyloarthropathy. J Rheumatol 2015;42:21-30.

J Rheumatol 2015;42:9; doi:10.3899/jrheum.141646 